David Renton

The New Authoritarians: Convergence on the Right

London: Pluto Press, 2019, 288 pp

\title{
Faustian Politics
}

\section{COLIN BARTON}

David Renton's The New Authoritarians addresses our current moment of societal crisis in the West, in which popular dissatisfaction with established political institutions, dealignment from traditional parties, and distrust towards the class of elites who occupy positions of power within them, has reached new heights. Citizens no longer feel these structures and systems can cater to their needs nor represent their identities. For liberal democracies, this widespread anti-elite and anti-establishment sentiment has culminated in a contemporary crisis of political authority-exemplified by events such as the election of Donald Trump and Brexit-engendering the emergence of different populist movements around the world. While these movements share common, often vague, democratic demands, some, such as the increasingly dominant national populisms, operate from far-right platforms of nativism, protectionism, discrimination, ethnonationalism, and authoritarianism, which rather than protect or advance democracy, threaten to dismantle it. ${ }^{1}$

The New Authoritarians is grounded in Renton's

1 Roger Eatwell and Matthew Goodwin, National Populism: The Revolt Against Liberal Democracy (London: Penguin Random House, 2018). 
historical, sociological, and political bibliography. Over the past 25 years, Renton has written extensively on the history of the Left-on worker movements and their struggles against domination in both the UK and internationally. Complimenting this focus, a major theme in Renton's research is fascism: its history, its modern incarnations, and how it has evolved. Renton has also been actively engaged in anti-fascist and socialist activism, allowing him to describe with first-hand expertise the current structure and organisation of both the far-right and the wider global movement of national populism, and to provide a pathway to how a reenergised Left can resist it.

Unlike many of his liberal contemporaries, Renton does not perceive the re-emergence of the far-right as an external force that has invaded Western democracy, but one that was internally and intentionally invited by the conservative centre. Renton's main premise is that many of the traditional political parties of the Right, aware of widespread political discontent and the rapid erosion of their authority to govern, have coalesced with, and pandered to, the increasing popularity of their radical ideological fringes, embracing the ideas of their outliers in an attempt to harness the populist Right's rising support and maintain their own power and relevancy. Using this dynamic of convergence as the focal point of his analysis, Renton argues that it is the willingness of traditional parties to work with the fringe that has legitimised and normalised many of the polices, ideals, and narratives that the far-right espouses, giving them influence far out of proportion to their actual base of support. In addition, not only have traditional parties directly cooperated with the far-right, but also, as in France and the UK, they have adapted their positions to better cater to, or even outdo, the agenda of national populism.

Renton stresses that this convergence is not a new phenomenon, but a strategy of political survival often used by parties of the centre to solidify their waning dominance and appeal to a wider slice of voters. His analysis of how fascism establishes itself reflects a number of Robert Paxton's arguments—specifically, how fascists utilise the stagnation and political deadlock of traditional parties to rise to prominence and, 
even more centrally, how conservatives invite fascists to share power under the assumption that they can be controlled. ${ }^{2}$ As during the chaos of the interwar years in Europe, this naïve presumption of traditional parties has backfired, with many of the previously marginalised but newly empowered fringe factions now dominating these parties and institutions, providing them with political influence to implement their political program.

To illustrate this process, Renton cites the current political polarisation in the US, describing the Tea Party and the wider reactionary shift of the Republican party, which even previous intellectual supporters Thomas Mann and Norman Ornstein now consider a 'radical insurgency'. ${ }^{3}$ Renton suggests that voter resentment towards the GOP's inability to oppose the polices of the Obama administration, such as the Affordable Care Act, resulted in a kind of crisis of representation for Republican voters, providing a space for an older version of conservatism to remerge. This ideology is often referred to as 'paleoconservatism', which has its origins in the regressive and isolationist 'Old Right' grouping of American politicians who opposed the New Deal and the new internationalism of America's agenda. It is defined by its overwhelming concern for an ethnically homogenous nation, scepticism of free markets, and the promotion of protectionism, traditionalist conservatism, and intense nationalism. ${ }^{4}$ The growing conservative disillusionment with the GOP allowed this previously supressed paleoconservative ideology, preserved by the party's hard-line factions, to re-emerge, eclipsing both neoconservatism and neoliberalism as the dominant Republican ideology and ushering in the reactionary political agenda of Donald Trump.

In the UK too, a small number of 'keepers of the Thatcherite flame', such as Nigel Farage and Arron Banks, successfully seized upon the

2 Robert Paxton, 'The Five Stages of Fascism,' The Journal of Modern History 70, no. 1 (1998): 1-23; The Anatomy of Fascism (New York: Random House, 2004).

3 Thomas Mann and Norman Ornstein, 'Finding the Common Good in an Era of Dysfunctional Governance,' Dedalus 142, no. 2 (2013): 15-25.

4 Michael Foley, American Credo: The Place of Ideas in American Politics (Oxford: Oxford University Press, 2007). 
opportunity that this moment of widespread dissatisfaction with the political system provided. ${ }^{5}$ These fringe political figures put the divisive issue of Brexit-a topic to which the UK public had previously been largely indifferent — at the centre of the UK's national discourse. In doing so, they were able to pressure and radicalise sections of the Conservatives, encouraging the party of pragmatic, free-market liberalism to adopt positions of nativism, nationalism, and protectionism, accented by fanciful dreams of Britannia reborn as a powerful global player. The dramatic shift in ideological direction by the traditional parties of the Right indicates not only their adaptation to the widespread scepticism with which many voters view globalisation and the international economic interdependence that has come with it, but also the willingness of these parties to implement the agenda of right-wing reactionaries, should it be politically advantageous.

Although these policy shifts have been an effort to capture voters from the fringe, it has legitimised many of the far-right's ideological positions previously seen as too dangerous and divisive to be included within mainstream political discourse. While the shift away from market fundamentalism is a significant ideological departure, the issue that best highlights this change is arguably immigration, on which the mainstream Right has almost universally adopted a more hard-line position. Again, Brexit exemplifies this: although often framed by Brexiteers as a virtuous crusade to return democratic or economic independence to 'the people' from the technocrats of Brussels, immigration was for many voters the key issue of the referendum. Catering to this attitude, migration was placed at the forefront of advertising and discourse by which the case for Brexit was made. Predictably, this focus played into the hands of advocates of classic far-right positions of homogeneity and ethnocentrism, and this Right was able to mobilise anti-immigrant and Islamophobic sentiments at the height of the EU's moral and organisational failure to respond to the refugee crisis and the fear it engendered. Brexit has had a lasting effect

5 David Renton, The New Authoritarians: Convergence on the Right (London: Pluto Press, 2019), 68. 
on the Conservative party, enabling previously marginalised traditionalist and 'one-nation' MP's like Jacob Rees-Mogg and Priti Patel to rise to prominence within the party and government, casting the liberal Tories to the backbenches, as these new reactionary paradigms are made gospel.

Exploring examples from the history of modern democracy and contrasting them with developments today, Renton suggests that efforts to harness these extreme elements by the centre have often backfired. His work shares several parallels with that of Steven Levitsky and Daniel Ziblatt, who stress the danger of traditional parties courting the fringe in the attempt to take advantage of their support, rather than maintaining political principle and stability in ensuring the exclusion of radical factions. ${ }^{6}$ Both texts base their warning of right-wing convergence in the seminal historical example of Weimar Germany. In the hope of regaining their political authority, and of suppressing a rising Leftist opposition, traditional conservatives conceded much to the National Socialists, empowering them in the process. ${ }^{7}$ Naïvely, the brokers of these bargains expected that they would maintain a level of control over the fascists, but these 'charismatic men of destiny' had plans of their own. ${ }^{8}$

Critical in the legitimisation of this new incarnation of the far-right has been the rebranding of its image in the attempt to appeal to a wider audience. Fundamental to this approach has been its disavowal of fascism and a stated rejection of racism. Renton warns of the danger this façade presents, allowing the far-right to simultaneously disavow discriminatory and authoritarian tendencies, while promoting them through carefully curated rhetoric and dog-whistling. Allegations of fascism are frequently levelled against the neo-reactionary Right, but Renton refutes these claims by delineating a non-fascist far-right. In doing so, he identifies the myriad of different groups that make up today's far-right scene, and

6 Steven Levitsky and Daniel Ziblatt, How Democracies Die: What History Reveals About Our Future (New York: Crown, 2018).

7 Paxton, 'The Five Stages of Fascism.'

8 Antonio Gramsci, The Antonio Gramsci Reader: Selected Writings 1916-1935, ed.

David Forgacs (New York: New York University Press, 1988), 218. 
traces their relation to right-wing populism, of which committed fascists make up a small, yet theatrical part. Indeed, accusations of fascism fail to discern the differences between the various factions of this movement and poorly interpret the ideology of fascism and the historical weight the word carries. Worse still, such accusations diminish fascism to a stylistic pejorative to be levelled at political opponents, rather than a true identification of immense barbarism. However, this qualification does not deny that the modern non-fascist far-right shares significant ideological overlaps with $20^{\text {th }}$-century fascism. What is clear is that the global rise of national populism and the ethnonationalist and authoritarian views espoused by its proponents has had a demonstratable effect in empowering neo-fascist groups, who feel legitimised by the political successes of their far-right brethren and the similarities between their ideological programs.

Part of this PR success is the far-right's use of new media, which has allowed them to develop a dominant online presence. Using digital platforms, they have melded internet trolling and social vandalism with overt white-supremacist narratives, creating a new, edgy front of the culture war that appeals to young voters and reactionaries alike, as exemplified by the Alt-Right. However, when the fascist and whitesupremacist overtones of this movement were laid bare during the 2017 Unite the Right rally in Charlottesville, the non-fascist far-right, which Renton asserts make up large segments of the Trump administration's political support, was forced to abandon their association with them. Despite this, there was a clear political logic in countersignalling this movement: the non-fascist far-right were able to present the Alt-Right and their loud, colourful figures, with whom they previously collaborated, as those who occupy the position of fascists and racists in an attempt to distance themselves from these labels. Renton highlights the removal of Steve Bannon-a divisive figure whose links to the online far-right are well documented - from the White House, as indicative of this approach of disavowal following the backlash to Charlottesville. Nonetheless, the president has largely continued to present himself as an ally to the far-right. Renton asserts that the convergence of the Right goes beyond single 
national political environments, referring to the internationalism of its political agenda. He describes the relationship between political insiders, media figures, and elected leaders that have supported and endorsed each other's agendas, providing strategic and political support to fringe figures in other nations, creating a disturbing global consensus around nativism, xenophobia, and authoritarianism. For this reason, he emphasises Bannon's role as a unifying figure of the far-right, who has worked hard to support populist campaigns in the US and internationally. Since being cast out of the White House, Bannon has focused on creating a network of far-right populist parties from South America to Europe, appearing frequently alongside populist leaders and dictators and providing them with strategic support. Bannon has openly expressed his desire to create a kind of reactionary international he calls 'the movement', and suggests that this wave of global national populism is the future of politics. His efforts have produced varying results, with some populist factions accepting his help gleefully, but with others dismissing Bannon's assistance due to ideological differences, or simply rejecting the notion that they require the political expertise of an American.

At first glance, an internationalist approach to nationalism seems contradictory. However, Renton suggests that the nationalism of today's globalised world is being redefined by more than the values of any single nation-state; more significant are "broader categories, such as "Western Civilization," or "the Judeo-Christian tradition"'. While such rhetoric creates a sense of solidarity among critics of globalisation, traditional conservatives, and anxious racial majorities, its primary logic is to appeal to, and promote, cultural chauvinism, white supremacy, and Islamophobia. This is evident in how the far-right uses such terminology, which consistently asserts the superiority of a culturally homogenous Western society and the fear that it is being eroded by multiculturalism, social progressivism, and marauding hordes of immigrants. Ironically, and quite contrary to the virtues the far-right espouses, these notions of Western defence are utterly saturated in identity politics and the desire

9 The New Authoritarians, 169. 
for a hegemonic bloc to be built around a particular identity they define as acceptable - reflected by the identities of populist candidates, rhetoric, and policies, which are explicitly based on exclusion.

Renton suggests that the recent victories of far-right populist outsiders have empowered and legitimised others around the globe who perceive these successes as a validation of their program and its palatability to voters. Indeed, the victory of Donald Trump as the 'leader of the free world' has legitimised and normalised the ideology of national populism around the world. In addition, Trump himself has been vocal in his affection towards other leaders of the far-right, often personally endorsing them and providing a surge in national support, as was seen with Marine Le Pen, for example.

Unlike many liberal scholars who prescribe political reformation within the halls of power as the solution to restoring 'normality', Renton suggests that the antidote lies in deconstructing and exposing the unholy alliance between traditional parties and the far-right through a popular Leftist mobilisation equipped with a new political program. He suggests that doing so will expose the values of bigotry and oppression that the far-right espouses, and the centre legitimises, forcing conservatism to abandon the policy of convergence and reject reactionary doctrine, lest they be conflated with it. For this reason, he again gives the example of the 2017 Charlottesville protests, in which Trump's links to the Alt-Right and their true nature were exposed to the horror of many Americans, forcing him to abandon his alliance with them. This had an immensely detrimental effect on the Alt-Right, which as a self-identifying movement has largely collapsed, and whose figures are now marginalised across the political divide. To this end, Charlottesville not only caused the rapid disintegration of one of the most well-known ethnonationalist movements at its zenith, but publicly linked the Trump administration with the empowerment of white supremacy, especially after the president's equivocation about 'violence on many sides'.

A more recent example of this dynamic was seen during the 2020 Thuringian government crisis, where Thomas Kemmerich of the liberal- 
centrist Free Democratic Party (FDP), came to power as minister president by courting the support of both the liberal-conservative Christian Democratic Union of Germany (CDU) and, startlingly, the far-right populist party Alternative for Germany (AFD) and its representative Björn Höcke (the leader of its extreme 'Flügel' faction, legally designated fascist). This was to be the first time since the Second World War that a far-right populist would be a part of a government in Germany. Across the political spectrum, significant condemnation of both the FDP and the CDU ensued over this coalescence and abandonment of principle, as working with the far-right has naturally been a long-held German taboo. The controversy culminated in Kemmerich's forced resignation, compelling the legislature to elect a president from the Left party (Die Linke), who had actually received the vast majority of the popular vote. This affair demonstrates the effectiveness of not only confronting the farright, but also those who collaborate and empower them for political advantage.

For this mobilisation to succeed, Renton suggests that the Left must undergo a process of renewal, from which it can transform itself into a true political alternative that opposes and challenges oppression, discrimination, and domination in all its forms, including that of the market and its masters. For this reason, the Left must cut its ties with the business community and wealthy donors to protect the integrity of its program. The popularity of Bernie Sanders and his campaign indicates the palatability of this approach. Renton stresses that the Left must not be passive; rather, it should actively confront the contemporary farright by exposing both their façade of non-racism and the traditional parties who enable them. Implementing these values in any meaningful way requires more than a mere rejiggering of democratic processes from the top-down: it will require an inclusive, pluralistic movement from below that mobilises itself in real space, and critically in relation to the convergence, holding elected officials accountable for their actions and associations. It will require a forceful abandonment of neoliberalism and a reintroduction of foundational Leftist principles- the protection 
and expansion of human dignity, social solidarity, and resistance to domination — to the heart of its political and economic program. Doing so will present a true alternative to both the vicious populism of the farright and the continual failures of the centre.

Critically, the Left must place inclusion at the centre of its values and approach. Too often, vocal portions of a young, enthusiastic Left embrace a toxic politics of fashionable moral absolutism, which, while seemingly originating in good intentions, is articulated through the exclusion and shaming of their perceived opponents. In erecting taut ideological standards, policing language, and marginalising those who disagree with even a fraction of the prescribed dogma, this methodology cannot hope to unite a broad coalition that encapsulates multiple identities, classes, and individuals. A movement that cannot grow beyond its own advocates is doomed to failure. Moreover, such a focus on ideological conformity has accelerated the loss of the Left's countercultural edge-a critical ingredient to any resistance against hegemony, and historically one of the Left's most effective weapons. Angela Nagle suggests that today's far-right now sees itself as occupying such a countercultural position, and that its emphasis on the transgression of humourless social norms and fomenting outrage are efforts to define itself as a subversive resistance to what it perceives as the hegemony of liberal, socially progressive culture. ${ }^{10}$ As the alt-lite agitator and conspiracy theorist Paul Joseph Watson proclaimed, 'conservatism is the NEW punk rock'. ${ }^{11}$ This widely promoted perception among the Right, of the Left as culturally dominant, has been reinforced by this new approach of censorship and public shaming.

It has become evident that this stylistic and somewhat decadent hypermoralism provides a steady stream of alienated recruits to the legions of the far-right. It must be recognised that marginalising and isolating people does not change minds or engender loyalty. In reality, these individuals

10 Angela Nagle, Kill All Normies: Online Culture Wars from Tumblr to Trump and the Alt-Right (Washington: Zero Books, 2017).

11 Paul Joseph Watson (@PrisonPlanet), 'Conservatism is the NEW counter-culture. Conservatism is the NEW punk rock. Everyone RT this, it really annoys leftists,' Twitter, 4 February 2017. 
are far more likely to be driven to the fringes, finding other outcasts who can nurture their resentment and provide an alternative political program. This is a dynamic that the modern far-right is keenly aware of, making use of it in the promotion of its ideas. Exclusion has always been a weapon of the Right's arsenal, and is not one the Left should employ, lest it seek to validate far-right narratives and criticisms.

Our current moment is one of extreme social and political crisis, where we can no longer rely on the robustness of liberal democracy to safeguard human dignity. New political paradigms based upon emancipation from all forms of oppression must be established by a broad coalition. Achieving this will require the contribution of a myriad of different identities, which while perhaps divided by irreconcilable differences, must be united by shared antagonisms and common demands for justice. 